\title{
LAND COVER CHANGE AND ITS INFLUENCE ON THE ASSESSMENT OF THE ECOLOGICAL STABILITY
}

\author{
MUCHOVÁ, Z.*-TÁRNÍKOVÁ, M. \\ Slovak University of Agriculture in Nitra, Tr. A. Hlinku 2, 94976 Nitra, Slovakia \\ *Corresponding author \\ e-mail: zlatica.muchova@uniag.sk; phone: +421-37-641-5216; fax: +421-37-641-559 \\ (Received $3^{\text {rd }}$ Nov 2017; accepted $7^{\text {th }}$ Mar 2018)
}

\begin{abstract}
In this contribution, a simple way of quantification of ecological changes in a territory is proposed. Six degrees of ecological stability (from 0 for an anthropic element to 5 for natural and natureclose environments) and a coefficient of ecological stability (CES) related to land cover have been used to measure local ecological stability. The cadastral territory Báb (near Nitra, Slovakia) was segmented into 1 ha sized squares $(1,870)$ to estimate ecological situation by fuzzy clustering. For each of the three time horizons, well documented time snapshots (distant past, present and possible future) of the model territory, three clusters with negative, neutral and positive ecological characteristics (CES based) were identified. Positive as well as negative changes have been detected and localized in space. Negative (from the past to the present state) and positive (landscape consolidation project based state) landscape development has been observed in the study area. Introduced procedures can help to assess effects of proposed ecological measures in land consolidation projects.
\end{abstract}

Keywords: coefficient of ecological stability, land time horizons, multicriterial analysis, clustering, Slovakia

\section{Introduction}

Monitoring of particular land elements, their spatial representation, spatial configuration, and dynamics (Lipský and Kvapil, 2000; Angelovičová et al., 2015) is used when observing landscape changes in time. Investigation of land development from the distant past to the present times is important for ecological analyses leading to proposals of sustainable land utilization. Many factors as climate change (Lovejoy and Hannah, 2005), urbanization (Izakovičová et al., 2017), deforestation (Padonou et al., 2017), water quality deterioration (Dumbrovský et al., 2016; Petrovič et al., 2017), natural disasters (Yu et al., 2010), soil degradation (Van Oost et al., 2000), loss of biodiversity (Verburg et al., 2009) do play a role.

Spatial heterogeneity expressed by the landscape structure is linked to functional properties of land and is determined by natural, semi-natural, and anthropogenic factors, see e.g. Hoang and Denmukhametov (2015). Landscape structure can be described by land use classes in a certain time (e.g. Munteanu et al., 2014). Detection of changes is possible by comparing several time horizons. Every landscape is characterized by two processes: the process of the destruction of the original structure and the consequent development of a new one (e.g. Špulerová et al., 2016).

Slovakia's landscape significantly changed particularly since the 50 's of the $20^{\text {th }}$ century when the large-scale farming was introduced (Tarasovičová et al., 2013; Žabenský et al., 2016). For about 50 years, any obstacle (balks, unpaved roads, drainage) was removed that hampered the large-scale land management. A landscape with an average land unit of approximately 250 ha causes increased water and wind erosion (Húska et al., 2017), deterioration of the water source quality (Pekárová and 
Pekár, 1996), low ecological stability and consequent decline in biodiversity (e.g. Bezák et al., 2016), whirlwinds, floods (Urban et al., 2013), and droughts (Tárník, 2017).

Since 1991, land consolidations (LCs) address the landscape issues in Slovakia, Muchová et al. (2017). LCs are considered in many countries (Hartvigsen, 2014, 2016) as unique tools, able to harmonize ownership (Noszczyk and Hernik, 2016; Jin et al., 2016), functionality and ecological measures (Moravcová et al., 2017). Land ownership defragmentation (Kwinta and Gniadek, 2017; Janus and Markuszewska, 2017; Muchová and Jusková, 2017; Muchová, 2017) is a prerequisite for wider regional development of rural areas, which includes improvements to public facilities in compliance with the protection of natural resources (Pasakarnis and Maliene, 2010; Sallaku et al., 2010).

In this contribution, the level of anthropogenic impacts on the landscape is quantified by detection, measuring, spatial localization, evaluation, and visualization of land use / land cover changes. Presented procedures are intended for objective assessment of A) the quality of ecological measures in a territory (proposals and implementations, current and historical situation) and B) for directing decision-making activities in compliance with the environmental protection.

\section{Material and methods}

Quantification of anthropogenic impacts on a landscape was processed as follows:

1. Selection of study area: A territory with finished land consolidation project was chosen to allow for assessment of possible future changes in the landscape.

2. Land cover classification: Refined land use classes from Slovak cadaster of real estates have been used as a basis for estimation of ecological stability of particular landscape elements.

3. Use of time horizons: Three well documented time snapshots (distant past, present and possible future) of the study area provided means for determining landscape changes.

4. Determination of local ecological stability: Six degrees of ecological stability and a coefficient of ecological stability have been introduced to measure and visualize the state of the landscape in a given time.

5. Segmentation and clustering: A grid with 1 ha sized squares was used to segment the study area. Similarity of the ecological stability in particular squares was estimated using a fuzzy analysis.

\section{Study area}

Cadastral territory Báb, 2,009.09 ha, (Fig. 1) is located in Nitra region, Nitra district. Agricultural land covers $83.4 \%$ of Báb total area (arable land $76.4 \%$ ), forests $6.9 \%$, water bodies $2.2 \%$, build-up areas $5.1 \%$ and other areas $2.5 \%$.

From the geographical point of view, the territory belongs to a hilly area with the relief formed by medium to mildly steep slopes with significant manifestations of water erosion and floods (Fig. 2A). The territory belongs to a dry and warm climatic area with frequent droughts. It is a typical land of intensive agricultural use with top-quality soils. The Báb creek flows through the territory with a small irrigation reservoir (Fig. 2B) of 18 ha and a capacity of $600,000 \mathrm{~m}^{3}$. Flora and fauna are dominated by xerophytic and thermophilic species, especially of the Pannonian origin. 

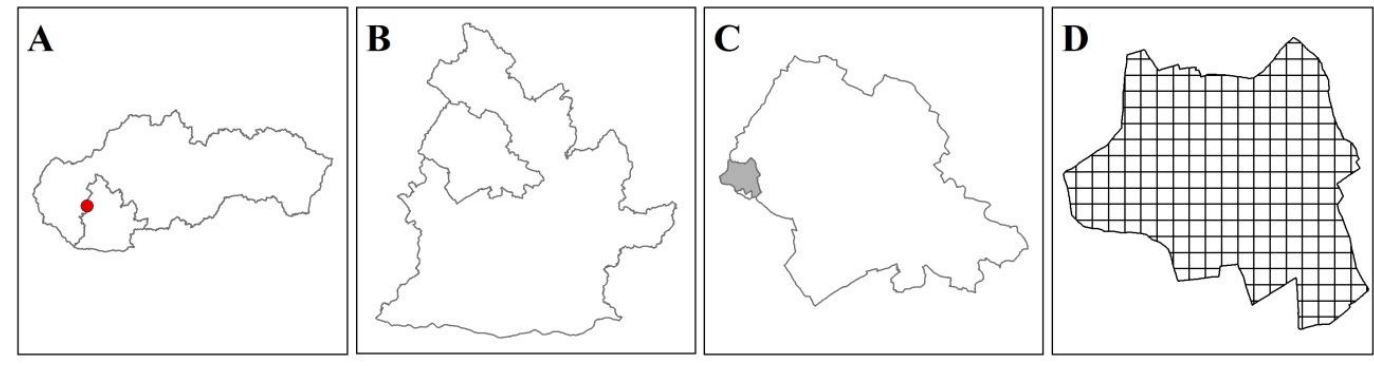

Figure 1. Báb location in A) Slovakia and region, B) region and district, C) district and cadastral area; $D$ ) border of the cadastral area and the grid with 1 ha sized squares
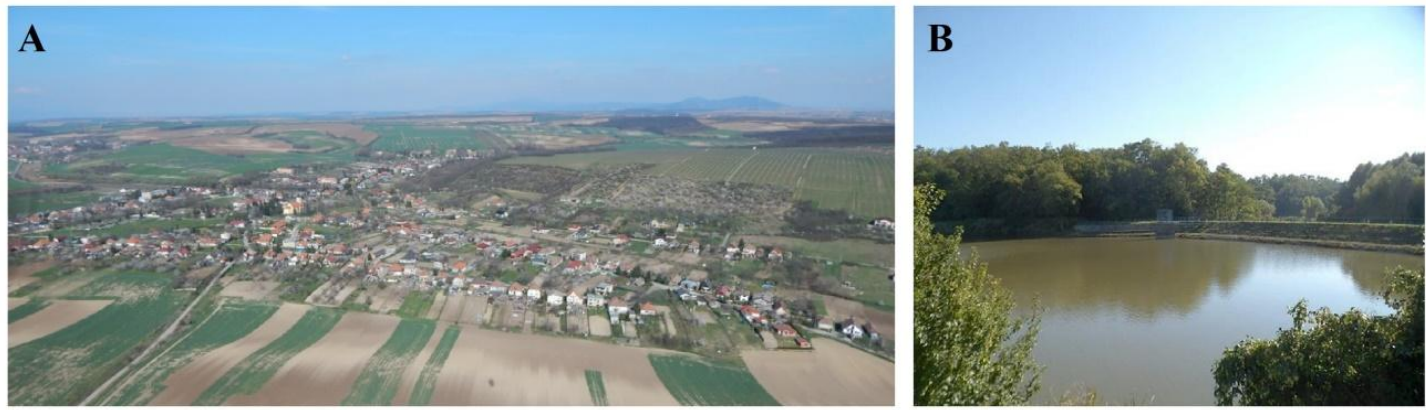

Figure 2. A) Báb landscape, B) irrigation reservoir

\section{Land cover classification}

The Slovak cadaster of real estates recognizes 10 land use (LU) classes (arable land, hop garden, vineyard, garden, orchard, permanent grassland, forest, water area, build-up area, and other area). All official maps use this nomenclature. LU classes are not suitable for quantification of ecological stability on a small scale, therefore refined LU elements have been used (Muchová et al., 2009).

\section{Time horizons}

Three time horizons, well-documented snapshots of the land use in Báb cadaster in distant past, present and possible future describe the landscape evolution. The first time horizon (TH1, distant past) represents historic land use (Fig. 3) in the year 1839 (second military mapping, also called Francis mapping, in the Austro-Hungarian Empire).
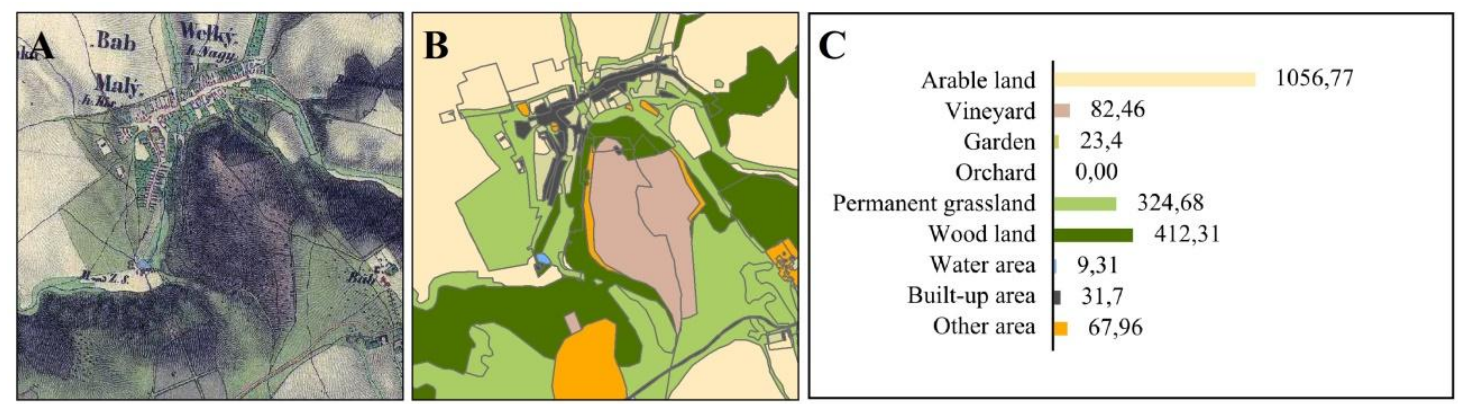

Figure 3. Distant past land use, TH1: A) military mapping II (geoportal.gov.sk), B) vectored map of land use classes, $C$ ) land use classes in ha 
The second time horizon (TH2, present) represents current land use (Fig. 4). Detailed mapping of the entire cadastral area was carried out in 2006 by Geotop Nitra and Geodézia Bratislava (with accuracy of $0.14 \mathrm{~m}$ ). The update from 2006 to 2016 was performed by additional measurements by the authors of this article. Only minor changes (on $1 \%$ of the territory) have been recorded.
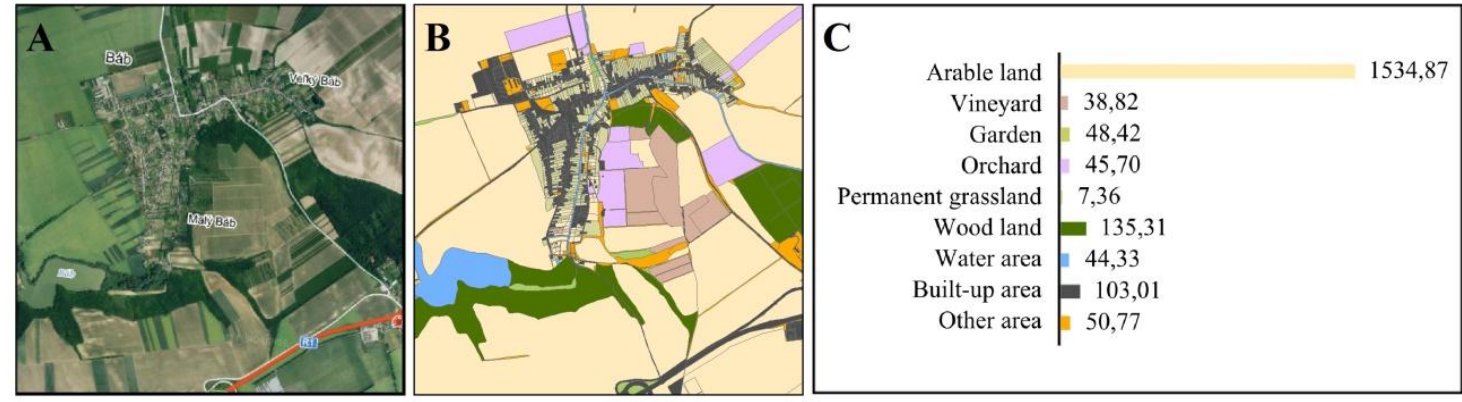

Figure 4. Present land use, TH2: A) orthophotomap (Eurosense), B) special purpose topographic mapping with land use classes, C) land use classes in ha

The third time horizon (TH3, possible future) represents proposed land use (Fig. 5). New functional arrangement of the territory after the land consolidation (LC) project with new roads, erosion control, water management, and ecological measures is binding and expected to be implemented in near future.
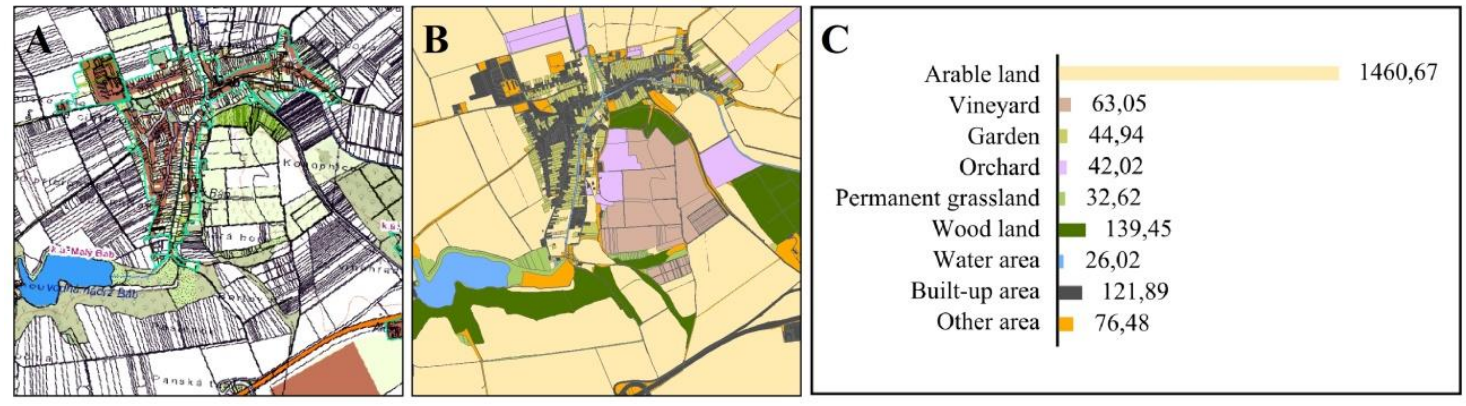

Figure 5. Possible future land use, TH3: A) cadastral map (https://zbgis.skgeodesy.sk), B) revised cadastral map with land use classes, C) land use classes in ha

\section{Determination of local ecological stability}

The ecosystems are best to be studied through elements of land use, as stated in several sources (e.g. Asner et al., 2004). In general, individual elements (refined land use classes) have a different character and different environmental quality (environmental stability). Each element is assigned a degree of ecological stability from 0 to 5 according to the origin of vegetation (Löw, 1995); 0 for an anthropic element, without vegetation and artificially designed (e.g. built-up areas, paved roads), 1 (e.g. intensively utilized, large-scale blocks of arable land), 2 (e.g. intensively used orchards, vineyards, reclaimed meadows), 3 (e.g. lawn orchards), 4 (e.g. forests, meadows with the predominance of naturally occurring species, natural water areas with semi-natural vegetation) and 5 for natural and nature-close environments (e.g. natural forests, natural 
herbaceous communities, wetlands, peat bogs, watercourses with natural bottom, banks and with characteristic water and coastal flora). Degrees of local ecological stability for past, present and future are depicted in Figure 6.
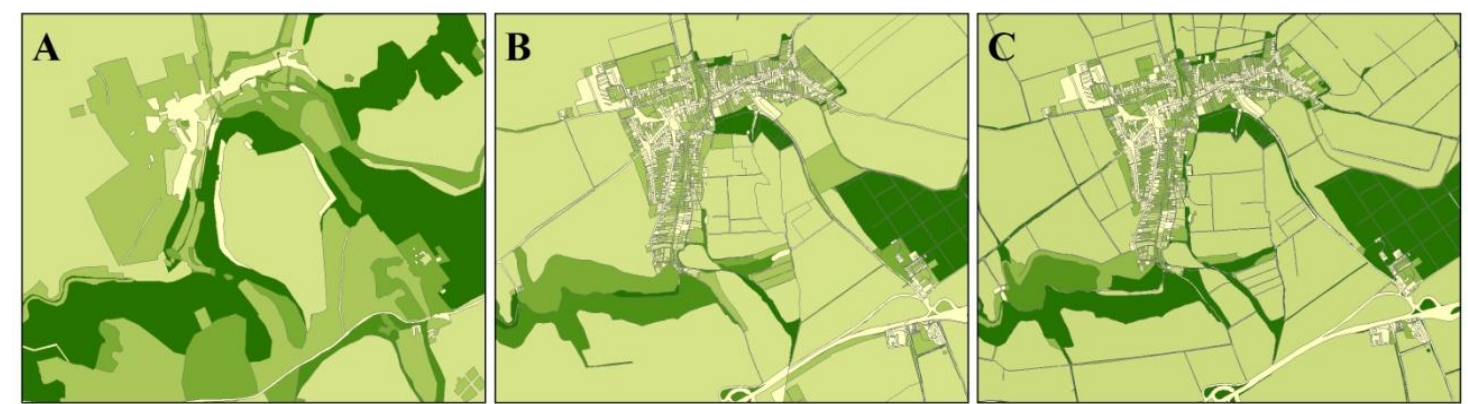

Degree $0 \quad$ Degree $2 \quad$ Degree 4

Degree $1 \quad$ Degree $3 \quad$ Degree 5

Figure 6. Degree of ecological stability for A) distant past land use, TH1, B) present land use, $\mathrm{TH} 2, \mathrm{C})$ possible future land use, $\mathrm{TH} 3$

A coefficient of ecological stability (CES) can be defined (Muchová et al., 2009; Muchová et al., 2016; Kupková, 2001; Stred’anský and Šimonides, 1995) as (Eq. 1):

$$
C E S=\frac{P_{5}+P_{4}+P_{3}}{P_{2}+P_{1}+P_{0}}
$$

$P_{i}$ variables ( $i$ from 0 to 5) denote the areas of refined land use classes of a given degree of ecological stability. CES is $<0.4$ for a landscape / area with very low ecological stability, $0.41-0.80$ low ecological stability, $0.81-1.20$ stable, $>1.21$ high ecological stability.

\section{Segmentation and clustering}

A grid with 1 ha sized squares was used to segment (see e.g. Muchová et al., 2015; Stejskalová et al., 2013) the Báb cadaster (Fig 1D). Local ecological stability (degrees of ecological stability of land use classes / elements and coefficient of ecological stability) was determined for each segment as described above.

Fuzzy clustering (R Core Team, 2017; Maechler et al., 2017) was applied to determine similarity of individual squares.

Ecological risk was estimated for each cluster using the CES value. Spatial analyses and map sets were processed by the GIS tool ArcMap 10.2 (ESRI, 2017).

\section{Results and discussion}

1,870 defined squares were assigned into three clusters (i.e. three for each time horizon) based on the similarity in local ecological stability (Fig. 7).

The clusters can be described as follows:

- Cluster characterized as negative contains 945 squares mostly in the degree 1 of ecological stability for the historical land use (TH1), i.e. $50 \%$ of the territory. 1,161 squares belong to it in present land use (TH2), also primarily in 
the degree 1 of ecological stability, covering $62 \%$ of the territory. 778 squares are members of it in the possible future land use (TH3), mostly degree 1 of stability ( $41 \%$ of the total area).

- Cluster with neutral characteristic contains 592 mostly ecological stability degree 2 squares $(31 \%)$ for the historical land use (TH1). 361 predominantly stability degree 2 and 3 squares $(19 \%)$ are assigned to it in present land use (TH2). 599 (32\%) mostly ecological stability degree 2 squares are members of it in the possible future land use (TH3).

- Cluster with positive characteristic contains 333 mostly ecological stability degree 5 segments (17\%) for the historical land use (TH1), 348 squares (18\%) of predominantly stability degree 3 and 5 in present land use (TH2) and 493 mostly ecological stability degree 5 squares $(26 \%)$ in the possible future land use (TH3).
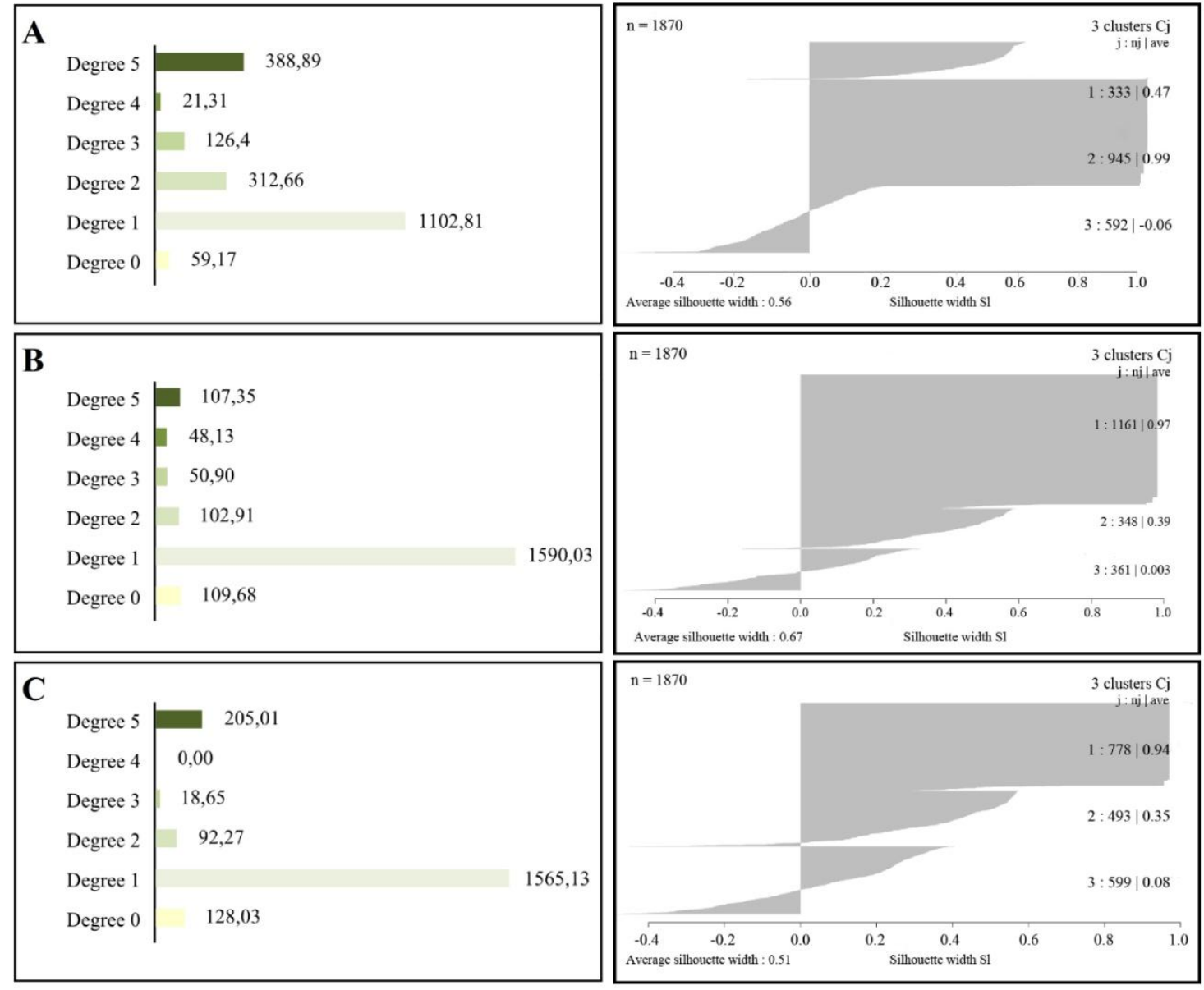

Figure 7. Local ecological stability for time horizons (in ha) and results of the cluster analysis A) TH1 (past), B) TH2 (present), C) TH3 (future)

The results of clustering have been visualized by marking individual segments according to cluster membership (Fig. 8).

Based on the spatial distribution of ecologically similar areas, the time evolution of the landscape can be observed (Fig. 9). 805 squares of land changed between past (TH1) and present (TH2) and 686 between TH2 and possible future (TH3). 


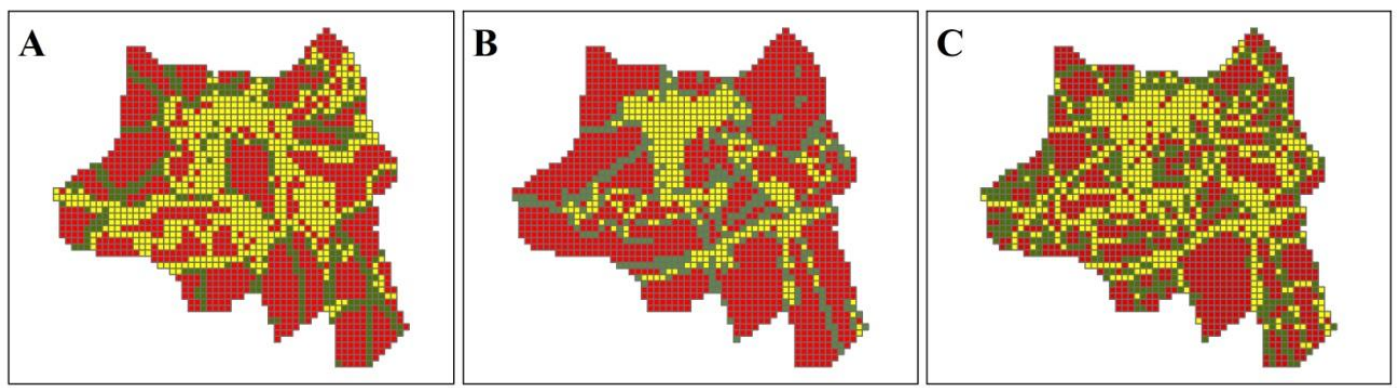

Negative $\square$ Neutral $\square$ Positive

Figure 8. Cluster membership of individual segments A) historical land use (TH1), B) present land use (TH2), C) possible future land use (TH3)

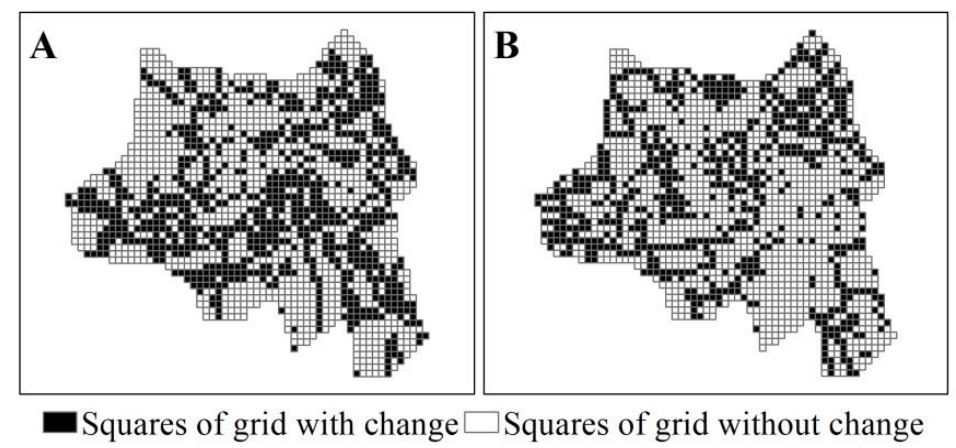

Figure 9. Local land cover changes: A) between past (TH1) and present (TH2), B) between TH2 and possible future (TH3)

A desirable (positive) local change can be identified when a segment moves from a lower to a higher category of cluster in time (Fig. 10A, B), negative change (Fig. 10C, $D$ ) means moving in the opposite direction in time.
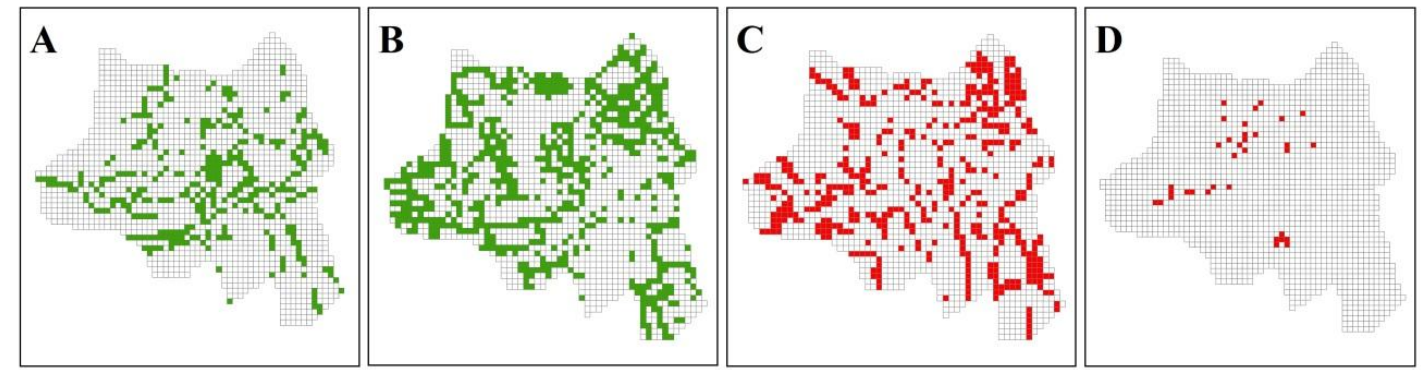

Positive change $=$ Negative change

Figure 10. Positive changes A) from $\mathrm{TH} 1$ to $\mathrm{TH} 2, \mathrm{~B}$ ) from $\mathrm{TH} 2$ to $\mathrm{TH} 3$. Negative changes $C$ ) from $\mathrm{TH} 1$ to $\mathrm{TH} 2, \mathrm{D})$ from $\mathrm{TH} 2$ to $\mathrm{TH} 3$

Ecologically negative changes clearly dominate in the landscape evolution from the past (TH1) to the present (TH2) state (463 squares, Fig. 10C). Positive changes are rarer (341 segments, Fig. 10A) and are connected to construction of road bodies with natural elements increasing the ecological stability such as tree lines, windbreaks or other 
habitat corridors (Fig. 11). The negative transformations are related to: ploughing the balks, groves, and small-scale elements of non-forest woody vegetation; construction of new buildings; turning marshlands and water areas into large-scale arable land or removing forest covers (Fig. 12).
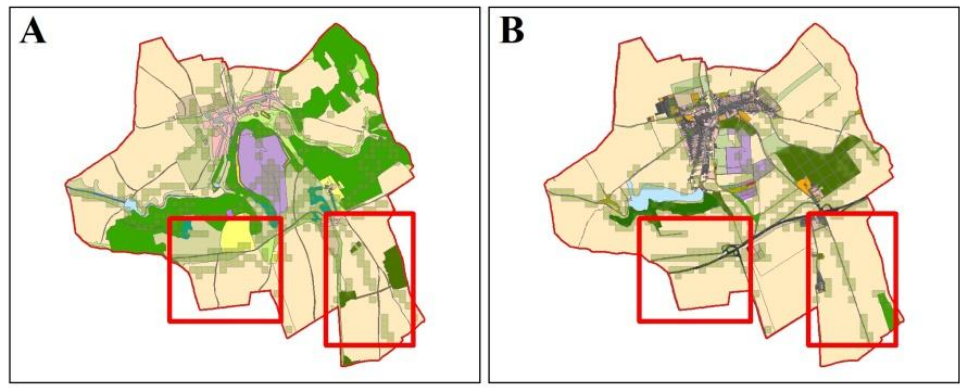

Figure 11. Unpaved roads with accompanying vegetation as an example of a positive change between the past $(A, T H 1)$ and the present $(B, T H 2)$ landscape

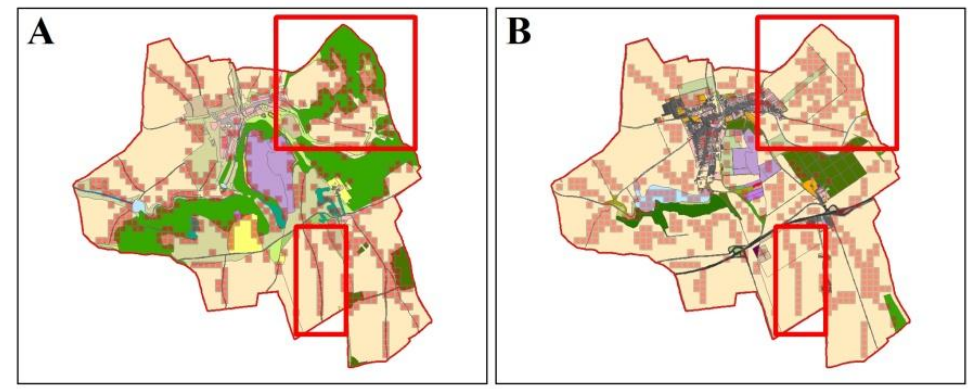

Figure 12. Examples of negative transformations (e.g. removing forest covers, ploughing balks) between the past (A, TH1) and the present (B, TH2) landscape

Land consolidation project (possible future land use, TH3) in the Báb area did not neglect ecological aspects as witnessed by the number of segments with positive changes between the present (TH2) state and the proposed (TH3) one (652, Fig. 10B). Through the LC project in the model territory, positive ecological changes were proposed on $35 \%$ of the total land area. Positive transformations (Fig. 13) include e.g. reinforced unpaved roads enriched by accompanying green such as windbreaks, habitat corridors, disruption of slopes by ditches; grassing the valley lines.

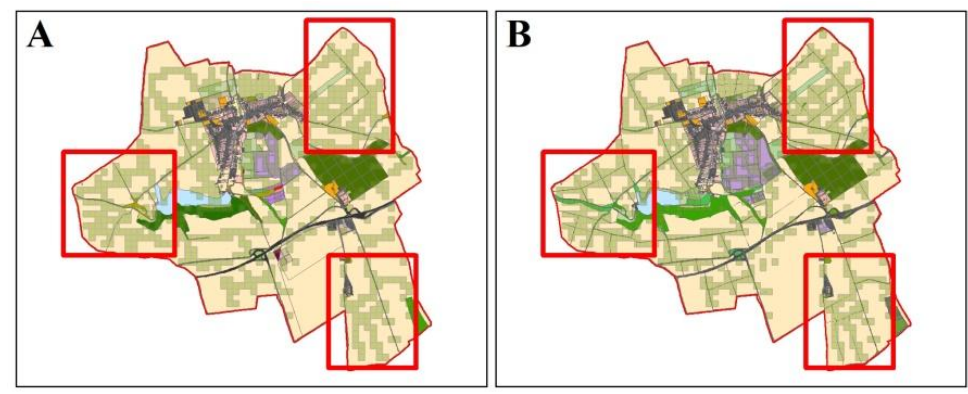

Figure 13. Localization of some positive changes (protective vegetation mostly) between the present $(A, T H 2)$ state and the proposed (B, TH3) one after the LC project 
Negative changes (between the present state and the proposed one) have been detected on 34 squares only (Figs. 10D and 14).
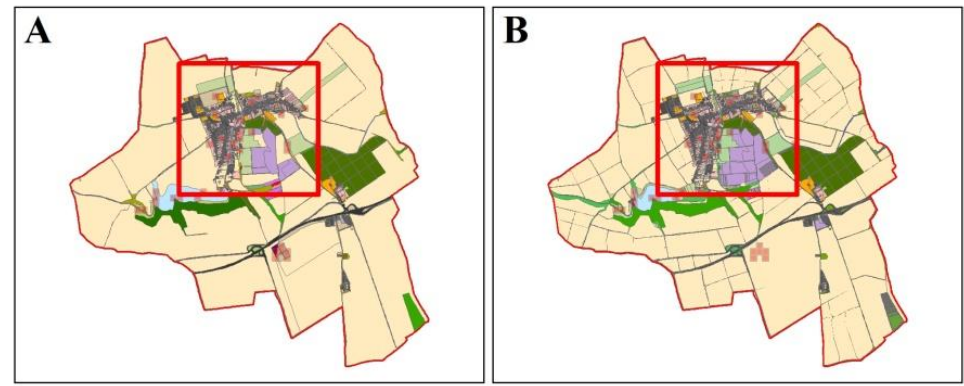

Figure 14. Localization of main negative changes (construction related) between the present $(A, T H 2)$ state and the proposed (B, TH3) one after the LC project

The changes observed when moving from the historical land structure (TH1) to the present day one (TH2), see Table 1, can be characterized by a significant increase in arable land $(+45.24 \%)$ and built-up areas $(+324.95 \%)$ accompanied by a decrease in permanent grassland $(-97.74 \%)$ and forests $(-67.18 \%)$.

Table 1. Changes (in ha) between TH1 (past land use) and TH2 (present land use), AL arable land, $\boldsymbol{V}$ - vineyard, $\boldsymbol{G}$ - garden, $\boldsymbol{O}$ - orchard, $\boldsymbol{P G}$ - permanent grassland, $\boldsymbol{F}$ - forest, $\boldsymbol{W A}$ - water area, $\boldsymbol{B A}$ - build-up area, $\boldsymbol{O A}$ - other area

\begin{tabular}{c|c|c|c|c|c|c|c|c|c|c}
\hline TH2/TH1 & AL & V & G & O & PG & F & WA & BA & OA & SUM TH2 \\
\hline AL & 946.05 & 32.52 & 3.05 & 0.00 & 241.32 & 255.53 & 3.13 & 5.18 & 48.09 & $\mathbf{1 5 3 4 . 8 7}$ \\
V & 0.26 & 31.42 & 0.30 & 0.00 & 1.76 & 4.38 & 0.00 & 0.14 & 0.56 & $\mathbf{3 8 . 8 2}$ \\
G & 10.82 & 0.00 & 8.22 & 0.00 & 11.59 & 6.24 & 0.45 & 8.70 & 2.40 & $\mathbf{4 8 . 4 2}$ \\
O & 17.93 & 11.69 & 0.12 & 0.00 & 4.49 & 8.58 & 0.00 & 0.00 & 2.89 & $\mathbf{4 5 . 7 0}$ \\
PG & 1.72 & 1.44 & 0.29 & 0.00 & 1.47 & 0.54 & 0.05 & 0.25 & 1.60 & $\mathbf{7 . 3 6}$ \\
F & 12.68 & 0.41 & 0.03 & 0.00 & 7.43 & 113.18 & 0.01 & 0.10 & 1.47 & $\mathbf{1 3 5 . 3 1}$ \\
WA & 14.54 & 0.00 & 0.94 & 0.00 & 13.55 & 11.49 & 3.08 & 0.60 & 0.13 & $\mathbf{4 4 . 3 3}$ \\
BA & 36.45 & 0.33 & 8.66 & 0.00 & 31.01 & 5.91 & 0.75 & 15.71 & 4.19 & $\mathbf{1 0 3 . 0 1}$ \\
OA & 16.32 & 4.65 & 1.79 & 0.00 & 12.06 & 6.46 & 1.84 & 1.02 & 6.63 & $\mathbf{5 0 . 7 7}$ \\
\hline SUM TH1 & $\mathbf{1 0 5 6 . 7 0}$ & $\mathbf{8 2 . 4 6}$ & $\mathbf{2 3 . 4}$ & $\mathbf{0 . 0 0}$ & $\mathbf{3 2 4 . 6 8}$ & $\mathbf{4 1 2 . 3 1}$ & $\mathbf{9 . 3 1}$ & $\mathbf{3 1 . 7 0}$ & $\mathbf{6 7 . 9 6}$ & \\
\hline
\end{tabular}

Land use changes from $\mathrm{TH} 1$ to $\mathrm{TH} 2$ definitely represent a negative development trend (particularly in relation to the ecological stability of the landscape). Many authors also do consider land interventions of the 50 's of the $20^{\text {th }}$ century negative due to the application of radical land reforms (Schmitt, 1993; Mathijs, 1997). According to Kabát and Hagedorn (1997), the primary goal of collectivization was to provide large-scale agricultural production and production increase at the expense of the land. Homogenization of the land and removal of its microstructure are typical features of the socialistic agriculture, see e.g. Bezák and Mitchley (2014). The original mosaic of 
arable land, meadows and pastures, marshlands, balks and groves, and unpaved roads turned into homogeneous areas of arable lands or meadows. Availability of the land both for biota and for humans decreased due to it (Young et al., 2007). According to McDonald (2013), a problem of the land future is also the farmer - their relationship with the land was destroyed during the socialist period by the forced collectivization with the consequent much more inconsiderate behavior of land users towards the environment.

Changes between present land structure $\mathrm{TH} 2$ and the possible future one (as proposed in the LC project) TH3 (Table 2) include a slight decrease of the arable land areas $(-5.00 \%)$. Splitting of large-scale land units by green areas can help to limit consequences of natural disasters. Permanent growth of built-up areas $(+18.00 \%)$ is caused mainly by establishing industrial zones and housing construction, which is typical for those cadastral territories located in close vicinity of district towns (Báb lies near Nitra on a highway). There is an expected increase of green spaces $(+444.42 \%)$, mostly in the form of protective vegetation - functional vegetation, original and unoriginal non-woody vegetation.

Table 2. Changes (in ha) between TH2 (present land use) and TH3 (projected future land use), $\boldsymbol{A} \boldsymbol{L}$ - arable land, $\boldsymbol{V}$ - vineyard, $\boldsymbol{G}$ - garden, $\boldsymbol{O}$ - orchard, $\boldsymbol{P G}$ - permanent grassland, $\boldsymbol{F}$ - forest, $\boldsymbol{W A}$ - water area, $\boldsymbol{B A}$ - build-up area, $\boldsymbol{O A}$ - other area

\begin{tabular}{c|c|c|c|c|c|c|c|c|c|c}
\hline TH3/TH2 & AL & V & G & O & PG & F & WA & BA & OA & SUM TH3 \\
\hline AL & 1453.95 & 0.42 & 2.19 & 0.00 & 0.01 & 0.10 & 1.61 & 1.60 & 0.79 & $\mathbf{1 4 6 0 . 6 7}$ \\
V & 23.06 & 36.49 & 0.00 & 2.82 & 0.00 & 0.00 & 0.00 & 0.00 & 0.68 & $\mathbf{6 3 . 0 5}$ \\
G & 0.04 & 0.00 & 44.54 & 0.03 & 0.00 & 0.00 & 0.02 & 0.00 & 0.31 & $\mathbf{4 4 . 9 4}$ \\
O & 0.01 & 0.00 & 0.00 & 41.88 & 0.00 & 0.00 & 0.00 & 0.00 & 0.13 & $\mathbf{4 2 . 0 2}$ \\
PG & 15.04 & 0.01 & 0.13 & 0.21 & 3.39 & 0.04 & 9.85 & 1.77 & 2.18 & $\mathbf{3 2 . 6 2}$ \\
F & 0.00 & 0.00 & 0.00 & 0.00 & 0.00 & 134.24 & 0.00 & 0.00 & 5.21 & $\mathbf{1 3 9 . 4 5}$ \\
WA & 0.19 & 0.00 & 0.00 & 0.01 & 0.00 & 0.00 & 25.59 & 0.00 & 0.23 & $\mathbf{2 6 . 0 2}$ \\
BA & 15.05 & 1.28 & 0.65 & 0.33 & 0.62 & 0.07 & 0.57 & 97.43 & 5.89 & $\mathbf{1 2 1 . 8 9}$ \\
OA & 26.75 & 0.08 & 0.95 & 0.44 & 3.32 & 0.87 & 6.75 & 2.51 & 34.81 & $\mathbf{7 6 . 4 8}$ \\
\hline SUM TH2 & $\mathbf{1 5 3 4 . 0 9}$ & $\mathbf{3 8 . 2 8}$ & $\mathbf{4 8 . 4 6}$ & $\mathbf{4 5 . 7 2}$ & $\mathbf{7 . 3 4}$ & $\mathbf{1 3 5 . 3 2}$ & $\mathbf{4 4 . 3 9}$ & $\mathbf{1 0 3 . 3 1}$ & $\mathbf{5 0 . 2 3}$ & \\
\hline
\end{tabular}

Since 1991, 427 LC projects and 23 implementations have been started in Slovakia. Correctly conceived LC projects are tackling the landscape issues as a whole. The realization of expected benefits requires interdisciplinary coordination (e.g. Pasakarnis and Maliene, 2010) and compliance with a methodology since the projects are related to areas as regional development, environment, agriculture, infrastructure... The ratio of positive to negative changes in properly designed land consolidation projects, as is the case for the Báb area, objectively shows that a project can bring positive (ecological) landscape interventions and reduce impacts of anthropogenic land interventions. Extensive land consolidations in the Czech Republic (Jusková and Muchová, 2014) with numerous realizations of proposed ecological measures (Moravcová et al., 2017) also provide experiences that point to a positive impact (Kaulich, 2013) of comprehensive transformations of rural landscape. The success in resolving landscape 
issues (including the ecological ones) is so predominant (Sklenička et al., 2009) that comprehensive landscape consolidation projects have priority and are expanding there. Correct quantification (detection, measurement, evaluation, localization, visualization) of impact of proposed measures on ecological stability is evidently possible (as documented above) and can help to ensure the materialization of expected benefits of regulated landscape interventions.

\section{Conclusion}

In order to be able to assess the ecological stability of a territory in the course of (anthropogenic) land interventions a correct quantification of the changes is needed. The aim of this paper was to propose a way to do it. Measurement of the ecological stability was based on six degrees of ecological stability and a coefficient of ecological stability (CES) related to land cover / origin of vegetation (from 0 for an anthropic element to 5 for natural and nature-close environments). The study area (cadastral territory Báb near Nitra, Slovakia) was segmented into 1 ha sized squares $(1,870)$ for the evaluation purposes. Similarity of ecological situation was estimated using fuzzy clustering. Three clusters with negative, neutral and positive ecological characteristics (CES based) were identified for each of the three time horizons, welldocumented time snapshots (distant past, present and possible future) of the model territory. Positive (segment moves from a lower to a higher category of cluster in time) and negative changes (segment moves from a higher to a lower category of cluster in time) have been detected and localized in space. The cadastral territory of Báb served as an example of both a negative landscape development (from past to the present) as well as positive interventions (proposed future state from the finished landscape consolidation project). The second case documented that properly designed land consolidation projects can bring about significant improvement of ecological stability (on $35 \%$ of the total area). Procedures introduced in this contribution can help to quantify effects of proposed ecological measures in land consolidation projects and thus aid in correct decision making.

Acknowledgements. Results from research conducted in VEGA no. 1/0673/16 and KEGA no. 008SPU4/2017 projects have been incorporated into this paper.

\section{REFERENCES}

[1] Angelovičová, L., Ivanová, M., Fazekašová, D., Michaeli, E., Solár, V. (2015): Landscape changes under the influence of long term mining activities. - International Multidisciplinary Scientific GeoConference Surveying Geology and Mining Ecology Management, SGEM 2(2): 947-954.

[2] Asner, G. P., DeFries, R. S., Houghton, R. (2004): Typological Responses of Ecosystems to Land Use Change. - In: DeFries, R. S., Asner, G. P., Houghton, R. A. (eds.) Ecosystems and Land Use Change. American Geophysical Union, Washington, DC.

[3] Bezák, P., Mitchley, J. (2014): Drivers of change in mountain farming in Slovakia: from the socialist collectivisation to the Common Agricultural Policy. - Regional Environmental Change 4: 1343-1356.

[4] Bezák, P., Halada, L., Gajdoš, P., David, S., Žila, P., Mojses, M., Boltižiar, M., Petrovič, F. (2016): The long-term socioecological research of landscape and biodiversity changes 
in the mountain area of the Poloniny National Park in context of global changes. Životné prostredie 50(2): 90-96.

[5] Dumbrovský, M., Sobotková, V., Šarapatka, B., Váchalová, R., Pavelková-Chmelová, R., Váchal, J. (2016): Long-term improvement in surface water quality after land consolidation in a drinking water reservoir catchment. - Soil and Water Research 10(1): 49-55.

[6] ESRI (2017): The Power of Mapping. [2017-10-10]. - http://www.esri.com/what-is-gis.

[7] Hartvigsen, M. (2014): Land reform and land fragmentation in Central and Eastern Europe. - Land Use Policy 36: 330-341.

[8] Hartvigsen, M. (2016): Land consolidation in central and Eastern Europe - integration with local rural development needs. - Paper presented at the 2016 World Bank Conference on Land and Poverty, Washington DC, March 14-18, 2016.

[9] Hoang, H., Denmukhametov, R. (2015): The analysis of environmental and anthropogenic factors influencing the landscape structure formation of the Kuang Bin province (central Vietnam). - Journal of Pharmaceutical, Biological and Chemical Sciences 6(6): 1666-1672.

[10] Húska, D., Jurík, L., Tátošová, L., Šinka, K., Jakabovičová, J. (2017): Cultural landscape, floods and remote sensing. - Journal of Ecological Engineering 18(3): 31-36.

[11] Izakovičová, Z., Mederly, P., Petrovič, F. (2017): Long-term land use changes driven by urbanisation and their environmental effects (example of Trnava City, Slovakia). Sustainability 9(1553): 1-28.

[12] Janus, J., Markuszewska, I. (2017): Land consolidation - A great need to improve effectiveness. A case study from Poland. - Land Use Policy 65: 143-153.

[13] Jin, X., Zhang, Z., Wu, X., Xiang, X., Sun, W., Bai, Q., Zhou, Y. (2016): Coordination of land exploitation, exploitable farmland reserves and national planning in China. - Land Use Policy 57: 682-693.

[14] Jusková, K., Muchová, Z. (2014): Options and trends of land consolidation in the Czech and Slovak republics, with regard to common historical development of ownership and usage rights. - SGEM 2(5): 471-478.

[15] Kabat, L., Hagedorn, K. (1997): Privatisation and Decollectivisation Policies and Resulting Structural Changes of Agriculture in Slovakia. - In: Swinnen, J. F. M. (ed.) Agricultural Privatisation, Land Reform and Farm Restructuring in Central Europe. Ashgate, Aldershot.

[16] Kaulich, K. (2013): Importance and prospect of land consolidation in the Czech Republic. - Zeitschrift fur Geodasie, Geoinformation und Landmanagement 138(3): 193-200.

[17] Kupková, L. (2001): Land Use as Indicator of the Antropogenic Impact on the Landscape. - In: Bičík, I. et a. (eds.) Land Use/Land Cover Changes in The Period Of Globalization. Proceedings of the IGU -LUUC International Conference, Prague.

[18] Kwinta, A., Gniadek, J. (2017): The description of parcel geometry and its application in terms of land consolidation planning. - Computers and Electronics in Agriculture 136: 117-124.

[19] Lipský, Z., Kvapil, D. (2000): Současné změny ve využívaní půdy (Nové funkce venkovské krajiny?) (Current Changes in Land Use (New Functions of Rural Landscape?)). - Životné prostredie 34(3): 148-153.

[20] Lovejoy, T. E., Hannah, L. (2005): Climate Change and Bio-Diversity. - Yale University Press, New Haven.

[21] Löw, J. (1995): Rukovět' projektanta místního územního systému ekologické stability metodika pro zpracování dokumentace. (Designer Handbook of the Local Territorial System of Environmental Stability - Methodology for Documentation Processing). Agroprojekt, Brno.

[22] Maechler, M., Rousseeuw, P., Struyf, A., Hubert, M., Hornik, K. (2017): Cluster Analysis Basics and Extensions. - R package version 2.0.5. 
[23] Mathijs, E. (1997): An Historical Overview of Central and Eastern European Land Reform. - In: Swinnen, J. (ed.), Political Economy of Agrarian Reform in Central and Eastern Europe. Avebury, Aldershot.

[24] McDonald, T. (2013): The process of collectivisation violence. - Europe-Asia Studies 65(9): 1827-1842.

[25] Moravcová, J., Koupilová, M., Pavlíček, T., Zemek, F., Kvítek, T., Pečenka, J. (2017): Analysis of land consolidation projects and their impact on land use change, landscape structure, and agricultural land resource protection: case studies of Pilsen-South and Pilsen-North (Czech Republic). - Landscape \& Ecological Engineering 13(1): 1-13.

[26] Muchová, Z. (2017): Assessment of land ownership fragmentation by multiple criteria. Survey Review 1-8. https://doi.org/10.1080/00396265.2017.1415663.

[27] Muchová, Z., Jusková, K. (2017): Stakeholders' perception of defragmentation of new plots in a land consolidation project: Given the surprisingly different Slovak and Czech approaches. - Land Use Policy 66: 356-363.

[28] Muchová, Z., Vanek, J., Halaj, P., Hrnčiarová, T., Konc, L., Raškovič, V., Stred’anská, A., Šimonides, I., Vašek, A. (2009): Methodical Standards for the Design of Land Consolidation. - Garmond, Nitra.

[29] Muchová, Z., Leitmanová, M., Petrovič, F. (2015): A more detailed approach to the assessment of the water erosion threat for a territory. - International Multidisciplinary Scientific GeoConference Surveying Geology and Mining Ecology Management, SGEM 3(2): 3-10.

[30] Muchová, Z., Leitmanová, M., Petrovič, F. (2016): Possibilities of optimal land use as a consequence of lessons learned from land consolidation projects (Slovakia). - Ecological Engineering 90: 294-306.

[31] Muchová, Z., Leitmanová, M., Jusková, K., Konc, L., Vašek, A. (2017): Identification of stagnation reasons in the field of land consolidation in Slovakia compared with the Czech Republic. - Journal of Water and Land Development 33(1): 141-148.

[32] Munteanu, C., Kuemmerle, T., Boltižiar, M., Butsic, V., Gimmi, U., Halada, L., Kaim, D., Király, G., Konkoly-Gyuró, E., Kozak, J., Lieskovský, J., Mojses, M., Müller, D., Ostafin, K., Ostapowicz, K., Shandra, O., Štych, P., Walker, S., Radeloff, V. C. (2014): Forest and agricultural land change in the Carpathian region - A meta-analysis of longterm patterns and drivers of change. - Land Use Policy 38: 685-697.

[33] Noszczyk, T., Hernik, J. (2016): Modernization of the land and property register. - Acta Scientiarum Polonorum - Formatio Circumiectus 15(1): 3-17.

[34] Padonou, E., Lykke, M., Bachmann, Y., Idohou, R., Sinsin, B. (2017): Mapping changes in land use/land cover and prediction of future extension of bowé in Benin, West Africa. - Land Use Policy 69: 85-92.

[35] Pasakarnis, G., Maliene, V. (2010): Towards sustainable rural development in Central and Eastern Europe: Applying land consolidation. - Land Use Policy 27: 545-549.

[36] Pekárová, P., Pekár, J. (1996): The impact of land use on stream water quality in Slovakia. - Journal of Hydrology 180(1-4): 333-350.

[37] Petrovič, F., Stránovský, P., Muchová, Z., Faltan, V., Skokanová, H., Havlíček, M., Gábor, M., Špulerová, J. (2017): Landscape-ecological optimization of hydric potential in foothills region with dispersed settlements - a case study of Nová Bošáca, Slovakia. Applied Ecology and Environmental Research 15(1): 379-400.

[38] R Core Team (2017): R: A language and environment for statistical computing. $\mathrm{R}$ Foundation for Statistical Computing, Vienna, Austria. - https://www.R-project.org/

[39] Sallaku, F., Jojiç, E., Tota, O., Huqi, B., Fortuzi, S. (2010): The role of land consolidation activities in the sustainable rural development in Albania. - Journal of Agricultural Science 42(3): 825-832.

[40] Schmitt, G. (1993): Why Collectivization of Agriculture in Socialist Countries Has Failed: A Transaction Cost Approach. - In: Csaki, C., Kislev, Y. (eds.) Agricultural Cooperatives in Transition. Westview Press, Boulder. 
[41] Sklenička, P., Hladík, J., Střeleček, F., Kottová, B., Lososová, J., Číhal, L., Šálek, M. (2009): Historical, environmental and socio-economic driving forces on land ownership fragmentation, the land consolidation effect and the project costs. - Agricultural Economics 55(12): 571-582.

[42] Špulerová, J., Dobrovodská, M., Lieskovský, J., Bača, A., Halabuk, A., Kohút, F., Mojses, M., Kenderessy, P., Piscová, V., Barančok, P., Gerhátová, K., Krajčí, J., Boltižiar, M. (2011): Inventory and classification of historical structures of agricultural landscape in Slovakia. - Ekológia (Bratislava) 30(2): 157-170.

[43] Stejskalová, D., Karásek, P., Tlapáková, L., Podhrázská, J. (2013): Landscape metrics as a tool for evaluation of landscape structure, a case study of Hubenov region, Czech Republic. - Acta Universitatis Agriculturae et Silviculturae Mendelianae Brunensis 61(1): 193-203.

[44] Stredanský, J., Šimonides, I. (1995): Landscaping. - VŠP, Nitra.

[45] Tarasovičová, Z., Saksa, M., Blažík, T., Falt’an, V. (2013): Changes in agricultural land use in the context of ongoing transformational processes in Slovakia. - Agriculture 59(2): 49-64.

[46] Tárník, A. (2017): Monitoring a bilancia zásob pôdnej vody v povodí rieky Nitra (Monitoring and balance of groundwater resources in the Nitra river basin). - Hydrologie malého povodí. Ústav pro hydrodynamiku AV ČR, Praha.

[47] Urban, T., Lackóová, L., Halászová, K., Stred’anský, J. (2013): Wind Erosion in the Agricultural Landscape. - Wydawnictwo Uniwersytetu Rolniczego w Krakowie, Krakow.

[48] Van Oost, K., Govers, G., Desmet, P. (2000): Evaluating the effects of changes in landscape structure on soil erosion by water and tillage. - Landscape Ecology 15(6): 477589.

[49] Verburg, P. H., van de Steeg, J., Veldkamp, A., Willemen, L. (2009): From land cover change to land function dynamics: A major challenge to improve land characterization. Journal of Environmental Management 90(3): 1327-1335.

[50] Young, J., Richards, C., Fischer, A., Halada, L., Kull, T., Kuzniar, A., Tartes, U., Uzunov, Y., Watt, A. (2007): Conflicts between biodiversity conservation and human activities in the Central and Eastern European countries. - Ambio 36: 545-550.

[51] Yu, G., Feng, J., Che, Y., Lin, X., Hu, L., Yang, S. (2010): The identification and assessment of ecological risks for land consolidation based on the anticipation of ecosystem stabilization: A case study in Hubei Province, China. - Land Use Policy 27(2): 293-303.

[52] Žabenský, M., Zima, R., Predanocyová, B., Hučková, J. (2016): The ideological direction of the society/individual in a specific historical period. - European Journal of Science and Theology 12(6): 223-232. 